\title{
Conception of gear ratios selection between the engine and the electric machine in the hybrid drive systems
}

\begin{abstract}
Modern vehicles with hybrid combustion-electric drive systems are an important element in the strategy for reducing fuel consumption and emissions of exhaust gas components. Determinant of the use and development is to achieve substantial benefits in terms of classical powertrain vehicles equipped with internal combustion engines. This paper presents the concept of kinematic ratio selection between the engine and the electric machine. This concept is based on the analysis of the internal combustion engine load caused by the resistances of motion and the best possible assessment of the additional load caused by the operation of the generator. It is proposed that the energy transferred to the generator was taken in a most preferred area of the engine performance characteristics and generator by changing kinematic ratio between the engine and the generator. The described concept can also be used for the recovery of vehicles braking energy.
\end{abstract}

Keywords: green vehicles, hybrid powertrain

\section{Koncepcja doboru przełożeń między silnikiem spalinowym a maszyną elektryczną w hybrydowych układach napędowych}

\begin{abstract}
Wspótczesne pojazdy o hybrydowych spalinow- elektrycznych układach napędowych sa istotnym ogniwem w strategii zmniejszania zużycia paliwa i emisji sktadników spalin. Determinanta ich stosowania i rozwoju jest uzyskanie istotnych korzyści w odniesieniu do klasycznych układów napędowych pojazdów wyposażonych w tlokowe silniki spalinowe. W prezentowanej publikacji przedstawiono koncepcję doboru przetożenia kinematycznego między silnikiem spalinowym a maszyna elektryczna. Koncepcja ta opiera się na analizie obciążenia silnika spalinowego oporami ruchu i ocenie najkorzystniejszego dodatkowego obciażenia generatorem. Proponuje się, aby energia przekazywana do generatora była pobierana $w$ najkorzystniejszym obszarze charakterystyki sprawności silnika spalinowego i generatora przez zmiany przełożenia kinematycznego między silnikiem spalinowym a generatorem. Opisana koncepcja może być również wykorzystywana przy odzyskiwaniu energii podczas hamowania pojazdu.
\end{abstract}

Słowa kluczowe: pojazdy ekologiczne, napęd hybrydowy

\section{Introduction}

The increasing legislative requirements regarding fuel consumption and exhaust emissions are forcing designers of reciprocating internal combustion engines to use increasingly sophisticated systems of: power, combustion and flue gas cleaning. Thus the cost of the drive units increase. One can get the impression that the increases in production costs impact the ecological effects less and less. In such circumstances it is reasonable to develop hybrid drive systems. The environmental benefits resulting from the use of hybrid propulsion systems are shown in Figure 1. These were obtained from studies described in [7]. It should be noted, however, that these benefits are visible in the urban test when engine is running with partial loads, a reverse trend can be expected in motorway part of EUDC test and the authors of the publication did not include such data. Hybrid drives are thought to combine the advantages of the different power sources operating in the assumed sequence of their cooperation. In literature publications on the development of the internal combustion engine cooperation with inertial energy battery [8] of the electromechanical system with an energy battery $[4,8]$ or gas turbine with an electric motor [3] can be found. One can also find studies on the power transmission of mechanical systems in hybrid vehicles [2].

In practice, the most widely used in automotive solutions are hybrid diesel-electric drives. Constructed types of hybrid diesel-electric drive systems can be divided into three groups:

\section{Wstęp}

Zwiększające się wymagania legislacyjne odnośnie zużycia paliwa i emisji składników spalin zmuszają konstruktorów tłokowych silników spalinowych do stosowania coraz bardziej wyrafinowanych układów: zasilania, spalania i oczyszczania spalin. Wzrastają więc koszty jednostek napędowych. Można odnieść wrażenie, że wzrosty kosztów produkcji coraz słabiej oddziałują na efekty ekologiczne. $\mathrm{W}$ takich uwarunkowaniach zasadne jest rozwijanie konstrukcji napędów hybrydowych. Korzyści ekologiczne wynikające ze stosowania hybrydowych układów napędowych przedstawiono na rys. 1. Uzyskano je z badań opisanych w publikacji [7]. Należy jednak zauważyć, że korzyści te są widoczne w teście miejskim, gdy silnik spalinowy pracuje z częściowymi obciążeniami. W części autostradowej testu EUDC można się spodziewać odwrotnej tendencji, a takich danych autorzy publikacji nie zamieścili. Napędy hybrydowe w założeniu mają łączyć korzystne cechy różnych źródeł napędu pracujących według założonej sekwencji ich współpracy. Istnieją opracowania opisujące współpracę silnika spalinowego z inercyjnym akumulatorem energii [8], elektromechanicznego układu $z$ akumulatorem energii $[4,8]$ lub turbiny spalinowej z silnikiem elektrycznym [3]. Są również opracowania dotyczące układów mechanicznych przeniesienia napędu w pojazdach hybrydowych [2].

$\mathrm{W}$ praktyce motoryzacyjnej najszersze zastosowanie mają napędy hybrydowe spalinowo-elektryczne. Konstru- 
- Micro hybrids with an electric machine capacity of about $5 \mathrm{~kW}$, whose role is limited to the start-stop function and the partial recovery of braking energy, where the drive between the crankshaft and the engine power is transmitted via a rubber belt.

- Mild hybrids with power of about $25 \mathrm{~kW}$, in which the electric machine is located between the combustion engine and the transmission. Hybrids of this type allow for combining of the power of the electric machine and the internal combustion engine and the energy recovery of braking and driving downhill. They also support the start-stop system, but do not allow driving with only an electric drive. In solutions of this type the rotor of the electric machine is integrated into the engine flywheel.

- Full hybrids with the electrical machine power of 40 to $70 \mathrm{~kW}$, which employ the lowest work areas of internal combustion engine and the electric machine, operating as either an electric motor or a generator.

The main rationale for the construction of this type of hybrid drives are:

- Obtaining lower fuel consumption and emission components in driving tests in comparison to the same class of vehicles powered by reciprocating internal combustion engines [7].

- The ability to combine the power of the electric motor and internal combustion engine.

- Energy recovery from braking and driving downhill.

- Being able to work in the regime of zero emission (for a large hybrid).

- Use of high torque electric motor for moving off from standstill.

This publication presents the issues of choice of gear ratios between the combustion engine and the electric machine for a full hybrid. Since the presented concept of gear ratio selection is based on the correlation of combustion engine load and electrical machine load described with universal (general) characteristics, the next part of the study will consider the accuracy of such mappings.

\section{Mapping moments of movement resistance on the universal characteristics of a combustion engine}

Universal characteristic of the reciprocating internal combustion engine, is based on a series of load characteristics removed at steady speeds. It is therefore not taking into account the static characteristic transient operating conditions of the engine. For this reason it can be applied to moments of resistance of a moving vehicle under steady conditions with an acceptable accuracy. Then the engine loading moment $T_{s}$ can be described as the sum of the moments of the rolling resistance of the vehicle $\mathrm{T}_{\mathrm{f}}$ and air $\mathrm{T}_{\mathrm{p}}$ :

$$
\begin{gathered}
\mathrm{T}_{\mathrm{s}} \cdot \eta_{\mathrm{m}} \cdot \mathrm{i}_{\mathrm{c}}=\mathrm{r}_{\mathrm{d}}\left(\mathrm{F}_{\mathrm{p}}+\mathrm{F}_{\mathrm{f}}\right)= \\
=\mathrm{r}_{\mathrm{d}}\left(0.613 \cdot \mathrm{C}_{\mathrm{x}} \cdot \mathrm{A} \cdot \mathrm{V}^{2}+\mathrm{m} \cdot \mathrm{g} \cdot \mathrm{f}\right)
\end{gathered}
$$

where: $\eta_{\mathrm{m}}$ - efficiency of the power transmission, $\mathrm{i}_{\mathrm{c}}$ - overall transmission ratio in the drive system, $r_{d}$ - dynamic radius of the vehicle wheel, $\mathrm{C}_{\mathrm{x}}-$ drag coefficient, $\mathrm{A}-$ vehicle frontal

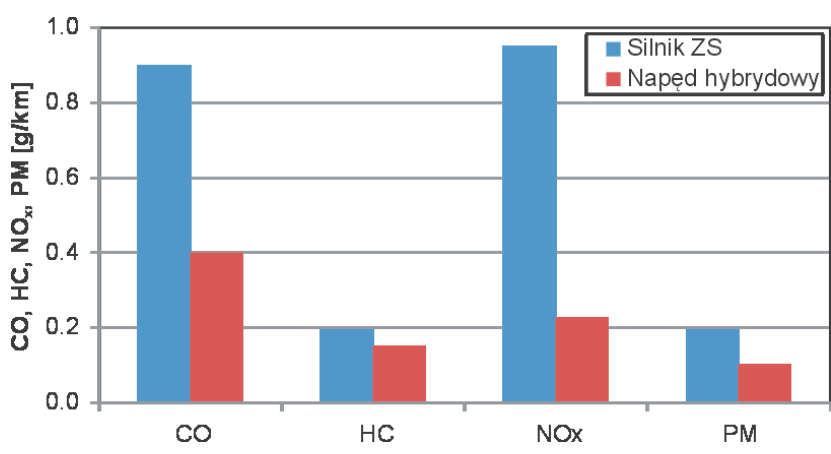

Fig. 1. Comparison of the emission components detected in a UDC test emitted by vehicles equipped with a diesel engine and with a hybrid drive [7] Rys. 1. Porównanie emisji składników spalin $w$ teście UDC emitowanych przez pojazd wyposażony $w$ silnik o zaptonie samoczynnym w odniesieniu do napędu hybrydowego [7]

owane hybrydowe spalinowo-elektryczne układy napędowe można podzielić na trzy grupy:

- Hybrydy mikro o mocy maszyny elektrycznej około $5 \mathrm{~kW}$, której rola ogranicza się do obsługi funkcji start-stop i częściowego odzysku energii hamowania, gdzie napęd między wałem korbowym silnika a maszyną elektryczną przekazywany jest pasem gumowym.

- Hybrydy średnie o mocy około 25 kW, w których maszyna elektryczna mieści się między silnikiem spalinowym i skrzynią biegów. Hybrydy tego typu pozwalają na łączenie mocy maszyny elektrycznej i silnika spalinowego oraz odzyskiwanie energii hamowania i zjazdu ze wzniesienia. Obsługują również układ start-stop, natomiast nie umożliwiają jazdy przy napędzie tylko elektrycznym. W rozwiązaniach tego typu wirnik maszyny elektrycznej jest zintegrowany z kołem zamachowym silnika spalinowego.

- Hybrydy pełne o mocy maszyny elektrycznej od 40 do 70 kW, w których wykorzystuje się najkorzystniejsze obszary pracy silnika spalinowego i maszyny elektrycznej, pracującej albo jako silnik elektryczny, albo jako generator.

Głównymi przesłankami do konstruowania tego typu napędów hybrydowych są:

- Uzyskiwanie niższych wartości zużycia paliwa i emisji składników spalin w testach jezdnych w porównaniu z pojazdami tej samej klasy napędzanymi łłokowymi silnikami spalinowymi [4].

- Możliwość łączenia mocy silnika elektrycznego i spalinowego.

- Odzyskiwanie energii hamowania i zjazdu ze wzniesienia.

- Możliwość pracy układu w reżimie zeroemisyjnym (dla hybrydy dużej).

- Wykorzystanie dużego momentu obrotowego silnika elektrycznego do ruszania z miejsca.

W niniejszej publikacji przedstawiono zagadnienia doboru przełożeń kinematycznych między silnikiem spalinowym i maszyną elektryczną dla pełnego napędu hybrydowego. Ponieważ prezentowana koncepcja doboru przełożenia opiera się na korelacji obciążeń silnika spalinowego i maszyny elektrycznej ujętych charakterystykami uniwersalnymi (ogólnymi), w dalszej części opracowania będą rozważone zagadnienia dokładności takich odwzorowań. 
surface area, $\mathrm{V}$ - vehicle velocity, $\mathrm{m}$ - the mass of the vehicle, $\mathrm{f}$ - the rolling resistance coefficient.

The relation connecting $V$ and $\omega$ is: $V=\left(\omega \cdot r_{d}\right) / i_{c}$.

In Figure 2 the curve $T_{s}$ depending on $\omega$ was applied on the sample universal characteristic of the internal combustion engine. This is a second degree curve obtained for the assumed fastest overall ratio in the driveline of the car. It cuts unit fuel use isolines $\mathrm{g}_{\mathrm{e}}$ at a considerable distance from the minimum value of $\mathrm{g}_{\mathrm{e}}$.

The universal characteristics for transient states can be used with some precision by introducing the relation [1], for which the transient torque Ts generated by the motor is reduced as a result of the instability of engine operation denoted with the symbol $\vartheta$ and the torque required to accelerate the rotating masses associated with the engine crankshaft:

$$
\left(\vartheta \mathrm{T}_{\mathrm{s}}-\mathrm{I}_{\mathrm{s}} \ddot{\varphi}_{\mathrm{s}}\right) \cdot \dot{\mathrm{i}}_{\mathrm{c}} \eta_{\mathrm{m}}
$$

where: $\vartheta$ - engine power loss factor (takes values of 0.95 0.98), $I_{\mathrm{s}}$ - mass moment of inertia, $\ddot{\varphi}_{\mathrm{s}}$ - angular acceleration of the rotating masses, $\mathrm{i}_{\mathrm{C}} \cdot \eta_{\mathrm{m}}$ - overall gear ratio between the engine and the wheels multiplied by the mechanical efficiency. This moment covers the movement friction of the vehicle (moments of these resistances):

$$
\begin{aligned}
& \left(\vartheta \mathrm{T}_{\mathrm{s}}-\mathrm{I}_{\mathrm{s}} \ddot{\varphi}_{\mathrm{s}}\right) \cdot \mathrm{i}_{\mathrm{c}} \eta_{\mathrm{m}}= \\
& =\mathrm{r}_{\mathrm{d}}\left(\mathrm{F}_{\Psi}+\mathrm{F}_{\mathrm{p}}+\mathrm{m} \ddot{\mathrm{x}}+\frac{\sum \mathrm{I}_{\mathrm{k}}}{\mathbf{r}_{\mathrm{d}}^{2}} \ddot{\mathrm{x}}\right) \\
& \frac{\vartheta \mathrm{T}_{\mathrm{s}} \cdot \mathrm{i}_{\mathrm{c}} \eta_{\mathrm{m}}}{\mathrm{r}_{\mathrm{d}}}=\vartheta \mathrm{F}_{\mathrm{n}} \\
& \vartheta F_{n}=F_{\Psi^{\prime}}+F_{p}+m \ddot{x}+\frac{\sum I_{k}}{r_{d}^{2}} \ddot{x}+\frac{I_{s} \ddot{\varphi}_{s} \dot{i}_{c} \eta_{m}}{r_{d}} \\
& \vartheta \mathrm{F}_{\mathrm{n}}=\mathrm{F}_{\Psi}+\mathrm{F}_{\mathrm{p}}+\mathrm{F}_{\mathrm{b}} \\
& \ddot{\varphi}_{\mathrm{s}}=\frac{\ddot{x}}{r_{d}} i_{c} \\
& F_{b}=m \ddot{x}\left(1+\frac{\sum I_{k}}{m r_{d}^{2}}+\frac{I_{s} i_{c}^{2} \eta_{m}}{m r_{d}^{2}}\right)= \\
& =m \ddot{x}\left(1+\delta_{k}+\delta_{s} i_{c}^{2}\right)=m \ddot{x} \delta_{b}
\end{aligned}
$$

$\delta_{\mathrm{b}}-$ is called the reduced mass coefficient, it expresses the number of times the replacement mass is greater than the gravitational mass. For precise calculations it is recommended to take the actual mass moments of inertia, so on average, $\delta_{\mathrm{k}}, \delta_{\mathrm{s}}(0.03-0.05)$

It can be mentioned that the author of the publication developed a method for obtaining the dynamic characteristics of the engine based on the combined data from the NEDC and FTP 75 driving tests [6]. But did not obtain satisfactory accuracy useful for analysis for the purposes of this publication.

\section{Odwzorowanie momentów oporu ruchu na charakterystyce uniwersalnej silnika spalinowego}

Charakterystyka uniwersalna spalinowego silnika tłokowego powstaje na podstawie serii charakterystyk obciążeniowych zdejmowanych przy stałych prędkościach obrotowych. Jest to więc charakterystyka statyczna nieuwzględniająca nieustalonych stanów pracy silnika. Z tego względu z zadowalającą dokładnością można nanieść na nią momenty oporów ruchu pojazdu w warunkach ustalonych. Wówczas moment obciążający silnik $\mathrm{T}_{\mathrm{s}}$ można opisać jako sumę momentów oporów toczenia $\mathrm{T}_{\mathrm{f}} \mathrm{i}$ oporu aerodynamicznego pojazdu $T_{p}(1)$, gdzie: $\eta_{\mathrm{m}}$ - sprawność przeniesienia napędu, $\mathrm{i}_{\mathrm{c}}$ - całkowite przełożenie $\mathrm{w}$ układzie napędowym, $\mathrm{r}_{\mathrm{d}}$ - promień dynamiczny koła pojazdu, $\mathrm{C}_{\mathrm{x}}-$ współczynnik oporu czołowego, A - powierzchnia czołowa pojazdu , Vprędkość pojazdu, $\mathrm{m}$ - jego masa, $\mathrm{f}$ - współczynnik oporu toczenia. Zależność wiążąca $\mathrm{V}$ i $\omega$ to: $\mathrm{V}=\left(\omega \mathrm{r}_{\mathrm{d}}\right) / \mathrm{i}_{\mathrm{c}}$.

Na rysunku 2 krzywą $\mathrm{T}_{\mathrm{s}} \mathrm{w}$ zależności od $\omega$ naniesiono na przykładową charakterystykę uniwersalną silnika spalinowego. Jest to krzywa drugiego stopnia uzyskana dla założonego najszybszego przełożenia całkowitego w układzie napędowym samochodu. Przecina ona izolinie jednostkowych zużyć paliwa $\mathrm{g}_{\mathrm{e}}$ w znacznej odległości od minimalnej wartości $\mathrm{g}_{\mathrm{e} 1}$.

$\mathrm{Z}$ pewną dokładnością można skorzystać z charakterystyki uniwersalnej dla stanów nieustalonych, wprowadzając zależności [1], dla których w stanach nieustalonych moment obrotowy generowany przez silnik $\mathrm{T}_{\mathrm{s}}$ jest pomniejszany w wyniku niestabilności pracy silnika ujętej symbolem $\vartheta$ i przez moment potrzebny do rozpędzania mas wirujących związanych z wałem korbowym silnika - wzór (2), gdzie: $\vartheta$ - współczynnik spadku mocy silnika (przyjmuje wartości 0,95-0,98), I - masowy moment bezwładności, $\ddot{\varphi}_{\mathrm{s}}$ - przyspieszenie kątowe mas wirujących, $\mathrm{i}_{\mathrm{C}} \cdot \eta_{\mathrm{m}}$ - przełożenie całkowite między silnikiem i kołami pomnożone przez sprawność mechaniczną. Moment ten pokrywa opory ruchu pojazdu (momenty tych oporów) - wzory (3) i (4); $\delta_{b}-$ nazywa się współczynnikiem mas zredukowanych; wyraża on ile razy masa zastępcza jest większa od masy grawitacyjnej. Do dokładnych obliczeń zaleca się przyjmować rzeczywiste masowe momenty bezwładności, a średnio $\delta_{\mathrm{k}}, \delta_{\mathrm{s}}(0,03-0,05)$.

Autor niniejszej publikacji opracował metodę otrzymywania charakterystyk dynamicznych silnika na bazie połączonych danych z testów jezdnych NEDC i FTP 75 [6]. Jednak nie uzyskał zadowalających dokładności przydatnych do analiz w prezentowanej publikacji.

\section{Koncepcja doboru przełożenia miĘdzy silnikiem spalinowym a generatorem}

Korzystając z zależności (1), dla wybranego przełożenia i kolejnych prędkości można nanieść na charakterystykę uniwersalną silnika parabolę zmiennego obciążenia silnika oporami ruchu. Na rysunku 2 naniesiono taką parabolę dla biegu najszybszego i ruchu ustalonego po płaskiej poziomej nawierzchni. Dla biegów o większych przełożeniach parabole momentów oporów ruchu będą położone poniżej paraboli biegu najszybszego. Dla danej prędkości kątowej 


\section{The concept of choice of transmission between the engine and the generator}

Using equation (1) for a chosen transmission ratio and further velocities a parabola of variable engine load with movement resistance can be applied onto the universal characteristic of the engine. In Figure 2, such a parabola was applied for the top gear and a determined movement set on a flat level surface. For larger gear ratios parabolas of moments of motion resistance will be situated below the top gear parabola. For a given angular velocity in specified traffic conditions, one can apply for example, point A, on the characteristics of a universal engine, Fig. 2 which will correspond to the values of $\mathrm{T}_{\mathrm{A}}$ and $\omega_{\mathrm{A}}$. If the car has an instantaneous acceleration then for the same angular velocity the load calculated from equation (3) can be applied. It will be a point lying above the point $A$.

On the example universal characteristic shown in Fig. 2 line of optimum operating conditions of the engine was applied, which was created by connecting the tangential baseline of unit fuel use with hyperbolas of constant power. It is the line of maximum engine efficiency. An internal combustion engine working with the angular speed $\omega_{\mathrm{A}}$ is laden with torque $\mathrm{T}_{\mathrm{A}}$ for the determined working conditions or in case of accelerated motion with torque $\mathrm{A}^{\prime}$ lying above and calculated from the relation (3).

For the same speed $\omega_{\mathrm{A}}$ engine load can be increased to point B lying on the optimum load line, which corresponds to the time $T_{B}$. The difference of moments $T_{B}-T_{A}$ may be loaded on the electric machine working in the generator mode. It should be noted that above a certain angular velocity of the motor the difference between the moment of optimum load and the moment of movement resistance decreases. It was visualized, as an example, for point $\mathrm{C}$, where the difference of moments is less than for point A. The presented solution shows that the greatest benefits from the torque surplus can be achieved at lower angular velocities and low loads. Such work conditions are present when driving in urban zones UDC in a NEDC test. At high loads and speeds, there may be practically no difference in moments (for example in EUDC). Hence the hybrid electric vehicle can generate benefits in urban traffic, in motorway traffic, however, due to the greater mass (about $400 \mathrm{~kg}$ ) may be less economic than a vehicle of the same type powered by only an internal combustion engine.

Optimal load line (target line) may differ depending on the hybrid powertrain control strategy adopted. Figure 3 shows the two control strategies adopted for two different combustion engines of Toyota Prius vehicles with displacements of 1.5 and $1.8 \mathrm{dm}^{3}$ [9].

It can be assumed that for both engines in the engine speed range lower than the maximum torque speed the target load line was used in accordance with the description adopted by the author of this publication. Above this speed, for the 1.5 $\mathrm{dm}^{3}$ engine, the target line optimal for the minimum specific fuel consumption was adopted, which has a side effect of lowering the dynamics the vehicle. For the $1.8 \mathrm{dm}^{3}$ engine the target line passes into the maximum engine loads, which improves the vehicle dynamics at the cost of a slight increase in w ustalonych warunkach ruchu można na charakterystykę uniwersalną silnika spalinowego (rys. 2) nanieść przykładowo punkt A, któremu będą odpowiadać wartości $\mathrm{T}_{\mathrm{A}} \mathrm{i} \omega_{\mathrm{A}}$. Jeżeli samochód ma chwilowe przyspieszenie, to dla tej samej prędkości kątowej można nanieść obciążenie obliczone z zależności (3). Będzie to punkt leżący powyżej punktu A.

Na przykładowej charakterystyce uniwersalnej przedstawionej na rys. 2 naniesiono linię optymalnych warunków pracy silnika, która powstała z połączeń stycznych izolinii jednostkowych zużyć paliwa z hiperbolami stałej mocy. Jest to linia najwyższych sprawności silnika. Silnik spalinowy pracujący z prędkością kątową $\omega_{\mathrm{A}}$ jest obciążony momen-

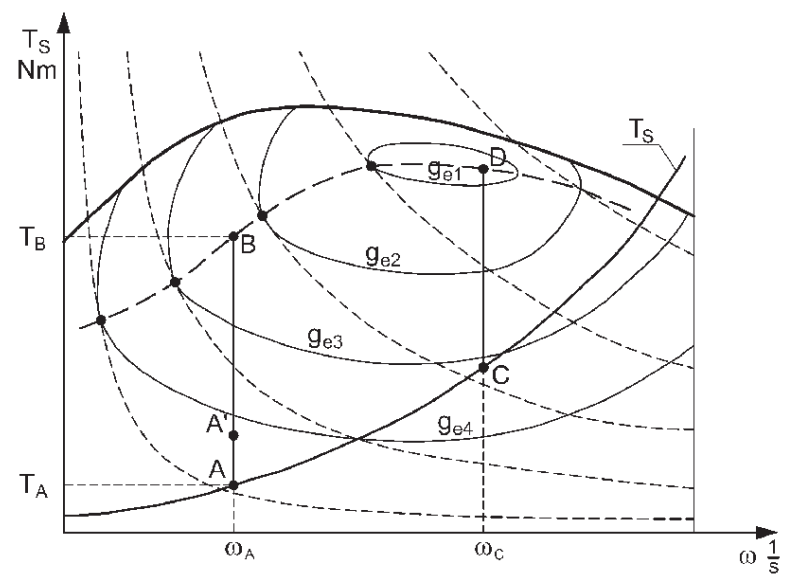

Fig. 2. Example of a universal reciprocating combustion engine characteristic with marked isolines of specific fuel consumption, constant power hyperbolas, the motion moment resistance curve in steady conditions Ts and the optimal engine load line (dashed line)

Rys. 2. Przyktadowa charakterystyka uniwersalna tłokowego silnika spalinowego z naniesionymi izoliniami jednostkowych zużyć paliwa, hiperbolami stałej mocy, krzywa momentu oporów ruchu w warunkach ustalonych Ts i linią optymalnych obciązeń silnika (linia przerywana)

tem obrotowym $\mathrm{T}_{\mathrm{A}}$ dla ustalonych warunków pracy lub, w przypadku ruchu przyspieszonego, momentem A' leżącym wyżej, a obliczonym z zależności (3).

Dla tej samej prędkości $\omega A$ można zwiększyć obciążenie silnika do punktu B leżącego na linii obciążeń optymalnych, któremu odpowiada moment $\mathrm{T}_{\mathrm{B}}$. Różnicą momentów $\mathrm{T}_{\mathrm{B}}-\mathrm{T}_{\mathrm{A}}$ można obciążyć maszynę elektryczną pracującą $\mathrm{W}$ trybie generatora. Należy przy tym zwrócić uwagę na to, że powyżej pewnej prędkości kątowej silnika maleje różnica między momentem obciążeń optymalnych a momentem oporów ruchu. Uwidoczniono to przykładowo dla punktu $\mathrm{C}$, gdzie różnica momentów jest mniejsza niż dla punktu A. Z przedstawionego rozważania wynika, ze największe korzyści z nadwyżki momentu można osiągać dla mniejszych prędkości kątowych i małych obciążeń. Takie warunki pracy występują przy jeździe miejskiej UDC w teście NEDC. Przy dużych obciążeniach i prędkościach różnica momentów (przykładowo w EUDC) może prawie nie występować. Wynika $\mathrm{z}$ tego, że pojazd $\mathrm{z}$ napędem hybrydowym może dawać korzyści w ruchu miejskim, natomiast w ruchu autostradowym z uwagi na większą masę (około 400 kg) może 


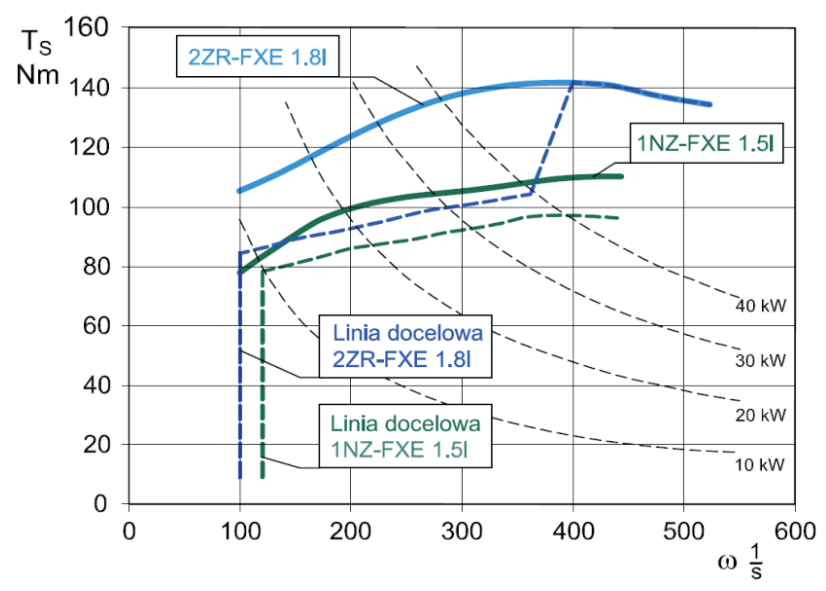

Fig. 3. Comparison of the control strategy of Toyota Prius hybrid powertrain for internal combustion engines used in different model generations [5]

Rys. 3. Porównanie strategii sterowania hybrydowych układów napędowych pojazdu Toyota Prius w zależności od zastosowanych silników spalinowych w poszczególnych generacjach modelu [5]

fuel consumption. For both engines, maximum traction loads occur very rarely because the vehicle is dedicated mainly to urban traffic. However, even in these operating conditions high instantaneous acceleration improves the active safety of the motor vehicle with the $1.8 \mathrm{dm}^{3}$ engine.

Generators used have their baseline performance characteristics, an example of which is shown in Fig. 4.

According to the author's proposal the most favorable point of the generator can be chosen as a tangent of the performance baseline to the constant power hyperbola resulting from the relationship $\left(\mathrm{T}_{\mathrm{B}}-\mathrm{T}_{\mathrm{A}}\right) \omega_{\mathrm{A}}$. The angular velocity $\omega_{\mathrm{G}}$ and the torque $T_{G}$ will correspond to this point, designated by $G$ on the characteristics of the generator. Therefore a transmission ratio being the ratio of the $\omega_{\mathrm{A}}$ to $\omega_{\mathrm{G}}$ should occur between the combustion engine and the generator. Such operating conditions of the generator can be achieved by using a continuously variable transmission (CVT) between the motor and the generator. An example schematic of a hybrid drive system using a continuously variable transmission between the combustion engine and the generator is shown in Fig. 5. The algorithm executed by the driver reads the combustion engine load (from the OBD system or calculated from the equations of motion) and from the map of the universal characteristics contained in the memory calculates the difference of moments and the power to be used by the generator. Using the efficiency maps of the generator the optimal angular velocity of the generator and optimum transmission $\mathrm{P}$ between the internal combustion engine and the electric machine is determined for the power baseline.

A similar course of action can be used during braking or for use of elevation energy provided knowledge of the characteristics of the resistance of the wheels of the vehicle driven by the combustion engine.

\section{Conclusions}

The presented concept of selection of the optimal kinematic ratio between the combustion engine and the electric być pojazdem mniej ekonomicznym od pojazdu tego samego typu, a napędzanego tylko silnikiem spalinowym.

Linia optymalnych obciążeń (linia docelowa) może przebiegać różnie w zależności od przyjętej strategii sterowania hybrydowym układem napędowym. Na rysunku 3 przedstawiono dwie strategie sterowania przyjęte dla dwóch różnych silników spalinowych samochodów Toyota Prius o pojemnościach skokowych 1,5 i 1,8 $\mathrm{dm}^{3}$ [9].

Można przypuszczać, że dla obydwu silników w zakresie prędkości obrotowych mniejszych niż prędkości maksymalnego momentu obrotowego przyjęto przebiegi linii obciążeń docelowych zgodnie z opisem przyjętym przez autora niniejszej publikacji. Powyżej tej prędkości dla silnika $1,5 \mathrm{dm}^{3}$ przyjęto przebieg linii docelowej optymalny dla minimalnego jednostkowego zużycia paliwa, czego skutkiem ubocznym jest spadek dynamiki samochodu. Dla silnika $1,8 \mathrm{dm}^{3}$ linia docelowa przechodzi w zakres maksymalnych obciążeń silnika, co poprawia dynamikę kosztem niewielkiego zwiększenia zużycia paliwa. Dla obydwu silników trakcyjne obciążenia maksymalne występują bardzo rzadko, gdyż samochód jest przeznaczony głównie do ruchu miejskiego. Jednak nawet w takich warunkach eksploatacji duże chwilowe przyspieszenia poprawiają bezpieczeństwo czynne samochodu z silnikiem $1,8 \mathrm{dm}^{3}$.

Stosowane generatory mają swoją charakterystykę izolinii sprawności, co przykładowo zilustrowano na rys. 4 .

Według propozycji autora tej publikacji można dobrać najkorzystniejszy punkt pracy generatora jako styczną izolinii sprawności do hiperboli stałej mocy wynikającej z zależności $\left(\mathrm{T}_{\mathrm{B}}-\mathrm{T}_{\mathrm{A}}\right) \cdot \omega_{\mathrm{A}}$. Temu punktowi oznaczonemu $\mathrm{G}$ na charakterystyce generatora będzie odpowiadała prędkość kątowa $\omega_{\mathrm{G}}$ i moment $\mathrm{T}_{\mathrm{G}}$. W związku z powyższym między silnikiem spalinowym a generatorem powinno wystąpić przełożenie kinematyczne będące stosunkiem $\omega_{\mathrm{A}}$ do $\omega_{\mathrm{G}}$. Takie warunki pracy generatora można uzyskać dzięki zastosowaniu bezstopniowej przekładni (np. CVT) między silnikiem i generatorem. Przykładowy schemat hybrydowego układu napędowego wykorzystującego bezstopniową przekładnię

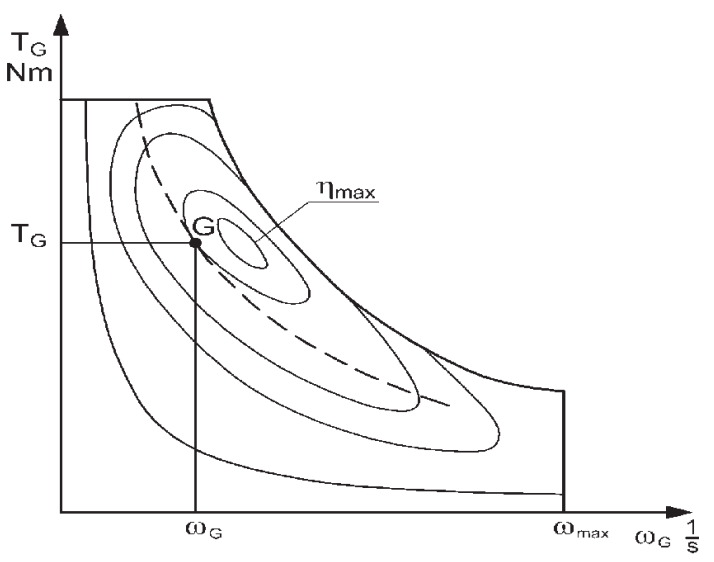

Fig. 4. An example generator characteristic with the of constant power hyperbola added (dashed line) as determined from the universal characteristics of the combustion engine

Rys. 4. Przykladowa charakterystyka generatora z naniesiona hiperbola stałej mocy (linia przerywana) wyznaczona z charakterystyki uniwersalnej silnika spalinowego 


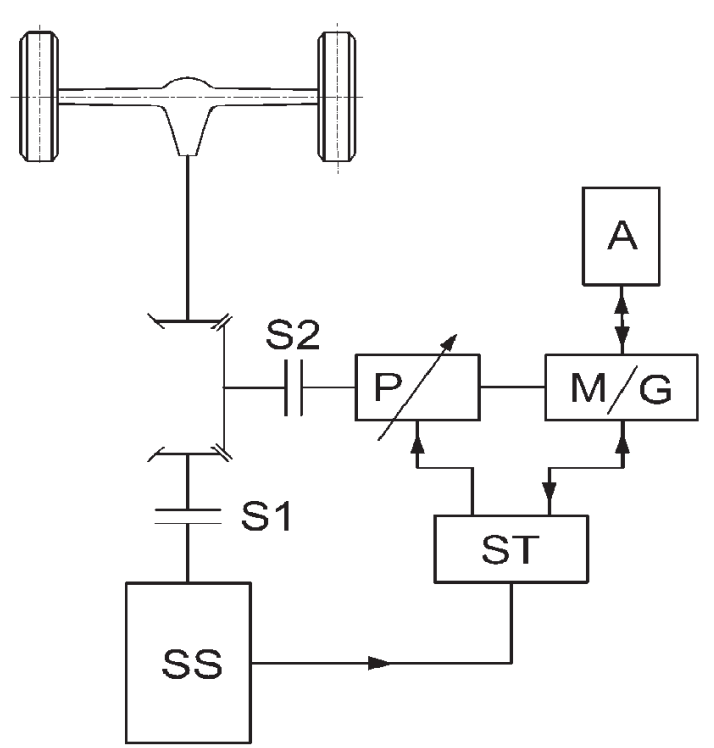

Fig. 5. An example diagram of a hybrid drive system allowing the use of an optimal kinematic ratio between the internal combustion engine and the electric machine (generator) M/G. S1 and S2 - clutches, ST controller P - continuously variable transmission, A - battery

Rys. 5. Schemat przyktadowego hybrydowego układu napędowego umożliwiającego wykorzystanie optymalnego przełożenia kinematycznego między silnikiem spalinowym SS a maszyna elektryczna (generatorem) $M / G$. S1 i $S 2$ - sprzęgła, ST-sterownik, $P$ - przektadnia o zmiennym przełożeniu, $A$-akumulator

machine of a hybrid vehicle powertrain is based on the simultaneous use of the best operating points of the two devices. To achieve the objective the following are necessary:

- the universal characteristic of the internal combustion engine,

- the efficiency characteristic of the electrical machine,

- the algorithm for determining the moments of resistance of a vehicle. This moment can be obtained from the OBD system or calculated from the relations shown in this study (more accurate values),

- the algorithm for calculating the optimal ratio between the combustion engine and the electric machine shown in this study.

The use of a transmission variator in a vehicle's drive system allows for obtaining the most effective resistance during braking, created by the generator with the clutch disengaged S1 as well as for clutch engaged S2.

Prof. Kazimierz M. Romaniszyn, DSc. DEng. Head of the Division of Vehicles in the Department of Internal Combustion Engines and Vehicles at Technical University of Bielsko-Biala.

Prof. dr hab. inż. Kazimierz M. Romaniszyn-kierownik Zakladu Pojazdów w Katedrze Silników Spalinowych i Pojazdów Akademii TechnicznoHumanistycznej w Bielsku-Białej.

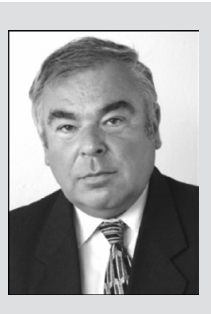

e-mail:kromaniszyn@ath.bielsko.pl między silnikiem spalinowym i generatorem przedstawiono na rys. 5. Algorytm realizowany przez sterownik odczytuje obciążenie silnika spalinowego SS (z systemu OBD lub obliczone $\mathrm{z}$ równania ruchu) i z zawartej w pamięci mapy charakterystyki uniwersalnej oblicza różnicę momentów i moc możliwą do wykorzystania w generatorze. Z mapy sprawności generatora określa dla izolinii mocy optymalną prędkość kątową generatora i optymalne przełożenie P między silnikiem spalinowym i maszyną elektryczną.

Podobny tok postępowania można zastosować przy hamowaniu lub wykorzystaniu energii wzniesienia pod warunkiem znajomości charakterystyki oporów silnika spalinowego napędzanego od kół pojazdu.

\section{Podsumowanie}

Zaprezentowana koncepcja doboru optymalnego przełożenia kinematycznego między silnikiem spalinowym i maszyną elektryczną hybrydowego układu napędowego pojazdu opiera się na równoczesnym wykorzystaniu najlepszych punktów pracy obydwu urządzeń. Do osiągnięcia założonego celu niezbędne są:

- charakterystyka uniwersalna silnika spalinowego,

- charakterystyka sprawności maszyny elektrycznej,

- algorytm określania momentów oporu ruchu pojazdu.

Moment ten można uzyskać z układu OBD lub obliczać z zależności podanych w niniejszym opracowaniu (wartości dokładniejsze),

- algorytm obliczania optymalnego przełożenia między silnikiem spalinowym i maszyną elektryczną podany w niniejszym opracowaniu.

Zastosowanie w układzie napędowym samochodu przekładni o zmiennym przełożeniu pozwala, przy hamowaniu, na uzyskiwanie najbardziej skutecznego oporu wytwarzanego przez generator przy wyłączonym sprzęgle S1 i załączonym S2.

\section{Bibliography/Literatura}

[1] Arczyński S. Mechanika ruchu samochodu. WNT, Warszawa 1994.

[2] Harbauer W. Moderne Antriebssysteme Fur Elektroautos Auswahlkriterium und Praktische Anwendung. VDI Berichte nr 1020, 1992.

[3] Merkisz J. Ekologiczne problemy silników spalinowych, tom 2. Wydawnictwo Politechniki Poznańskiej, Poznań 1999.

[4] Michałowski K., Ocioszyński J. Pojazdy samochodowe o napędzie elektrycznym i hybrydowym. WKŁ, Warszawa 1989.

[5] Pielecha I., Cieślik W., Borowski P., Czajka J., Bueschke W. The development of combustion engines for hybrid drive systems. Combustion Engines. 2014, 158(3), 23-35. ISSN 2300-9896.

[6] Romaniszyn K. Alternatywne zasilanie samochodów benzyną oraz gazami LPG i CNG - badania porównawcze dynamiki rozpędzania oraz emisji spalin. WNT, Warszawa 2007.

[7] Schweimer G., Kalberlah A. Oko und Hybrid-Antriebe fur den Citywerkehr - Technik und Kundenakzeptanz. Kolloqium „Fahrzeug und Mototechnik”, Aachen 1989.

[8] Szumanowski A. Akumulacja energii w pojazdach. WKŁ, Warszawa 1984.

[9] Uehara.T., Takahashi Y., Oki R., Hirasawa T. et al. Development of the New THS-II Powertrain for Compact Vehicles, SAE Technical Paper 2012-01-1017, 2012. 